\title{
Amphibian situation in urban environment - history of the common toad Bufo bufo in Kraków (Poland)
}

\author{
"Karolina A. Budzik, "** Krystian M. Budzik, "Krystyna Żuwała \\ *Department of Comparative Anatomy, Institute of Zoology, Jagiellonian University, \\ Gronostajowa 9, 30-387 Kraków, Poland \\ **Institute of Botany, Jagiellonian University, Lubicz 46, 31-512 Kraków, Poland, krystian.budzik@uj.edu.pl
}

\begin{abstract}
Rapid urbanization processes are not neutral to the environment, especially amphibians. Their double-environment lifestyle makes them particularly vulnerable to negative changes in the environment. Inventory research on batrachofauna carried out in urban areas usually provides data on its current state, but there is little information about changes in its composition over the years. The aim of the study was to investigate the situation of amphibians in urban areas of Kraków (Poland) over the last 90 years. As an example of amphibian species the common toad Bufo bufo (Linnaeus, 1758) was selected, because of its widespread occurrence and high environmental plasticity. Three periods were chosen for the analysis: 1) before the Second World War (1928-1939), when the nature of the city seemed to be the least exposed to treats, 2) after the rapid urban transformation associated with the expansion of the territory of the city (1986 -1992), and 3) the present time. In order to determine the current situation of amphibians, in 2011-2012, 30 water bodies of Kraków were inventoried, with particular emphasis on the common toad. The occurrence of the same species in the city over the last 90 years was shown. The proportion of occupied habitat $(\mathrm{POH})$ by the common toad (POH=0.57) is currently similar to the pre-Second World War proportion $(\mathrm{POH}=0.58)$. Between these two periods, there was a significant increase in the number of Bufo bufo in Kraków ( $\mathrm{POH}=0.86)$. At that time the common toad was the only amphibian which increased, while the others declined. These results may suggest the high resistance of the species to the negative impact of urbanization during this period (loss and fragmentation of habitat and pollution). However, its resistance is limited, as evidenced by the recent decline of the species, just as most other amphibians of Kraków.
\end{abstract}

Key words: urbanization, water bodies, historical inventory data, revision of species distribution.

\section{Introduction}

It is globally known that amphibians decline and that, among the world's vertebrates, the proportion of amphibious species on the verge of extinction is the highest (Stuart et al. 2004; Beebee \& Griffiths 2005). The main reasons for this are habitat loss, fragmentation and degradation. These threats are mostly associated with the process of urbanization, which is claimed to have the greatest impact on amphibian populations (Baillie et al. 2004; Stuart et al. 2004; Beebee \& Griffiths 2005; Cushman 2006). In addition to the previously mentioned threats, city development changes also cause hydrology amendments via the construction of impervious surfaces. This increases runoff, sedimentation and the pollution of streams and wetlands (Paul \& Meyer 2001; Miltner et al. 2004; Hamer \& McDonnell 2008). These factors are not indifferent to amphibian populations, whose reproduction depends on water (Juszczyk 1987; Stebbins \& Cohen 1995).

The city is a good area for research, as it is a place of rapidly occurring changes in the environment. With the evolving landscape, the amphibian species composition may also be changing. Among many studies on the decrease of the number of amphibians, there is little data from long-term research in cities (Ogielska \& Kierzkowski 2010; Najbar 2010). Among Polish cities, Kraków’s research on amphibians has the longest history (Juszczyk 1989; Guzik et al. 1996; Kawalec 1998; Kawa et al. 2011). 
Many years of research on batrachofauna allow us to look at its situation from a broader perspective. To trace the condition of batrachofauna in the face of urban changes, the common toad Bufo bufo (Linnaeus, 1758) was selected as an example of an amphibian. Due to its high environmental plasticity (Juszczyk 1987), it was expected that the ongoing urban processes would not be too detrimental for its population.

The common toad is one of 18 native amphibian species in Poland (Juszczyk 1987; Głowaciński \& Rafiński 2003), where it is very common. The species probably occurs throughout the country, where it occupies both lowlands and mountains (Głowaciński 2003). Due to the massive mating in early spring and associated migrations (Juszczyk 1987), the species is relatively easy to follow and establishing its presence during the mating season does not cause many problems. The $B$. bufo have a tendency to breed in the same location as where they were born, even if other breeding areas are available nearby. This increases their susceptibility to landscape development by humans (Wilkinson \& Buckley 2012).

The main goal of the study was to review data on the occurrence of the common toad in Krakow, as compared to other species of amphibians over the last 90 years of urbanization in the city.

\section{Materials and methods}

\subsection{Study area}

\subsubsection{Kraków city}

Kraków is located in southern Poland, in the central-northern part of the Małopolska province. The city is situated on the Vistula River and on its territory the Vistula River tributaries such as Prądnik, Rudawa and Wilga are located.

Before the Second World War, Kraków was characterized by an abundance of greenery, unpolluted air and a Vistula unpolluted by industrial waste. In 1945 the suburban districts were formally incorporated into the city, and soon after that, it began to follow radical and irreversible changes in urban planning. New settlements, factories and roads were constructed. The spontaneous development of local and outside local industry took place in isolation from the basic principles of environmental protection, without taking into account ecological tolerance to contamination and with the absence of a forward-looking assessment of the effects of such activities on the urban agglomeration of Kraków. Since then, as a result of air, soil, surface water and vegetation contamination, rapid and complete degradation of urban living environments has taken place (Juszczyk 1989). Urban processes still happen in Kraków today, although with a slightly greater environmental awareness.

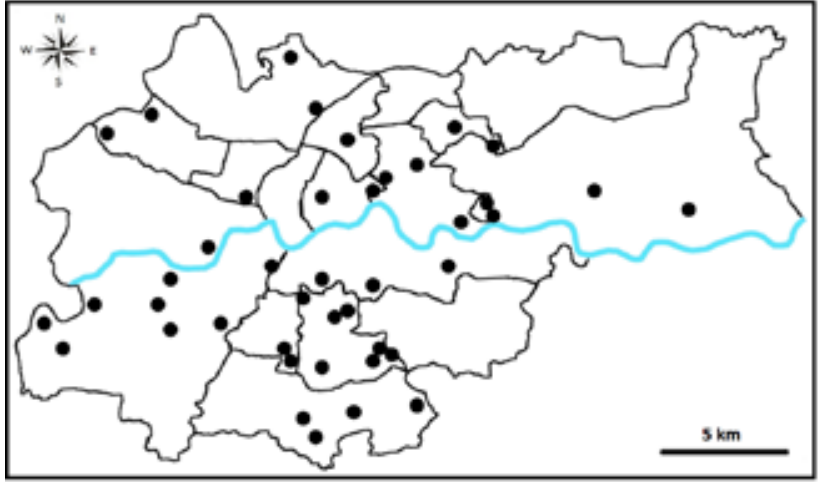

Figure 1. Distribution of all 42 actually (2011-2012) studied sites in Kraków (within borders of the city districts)
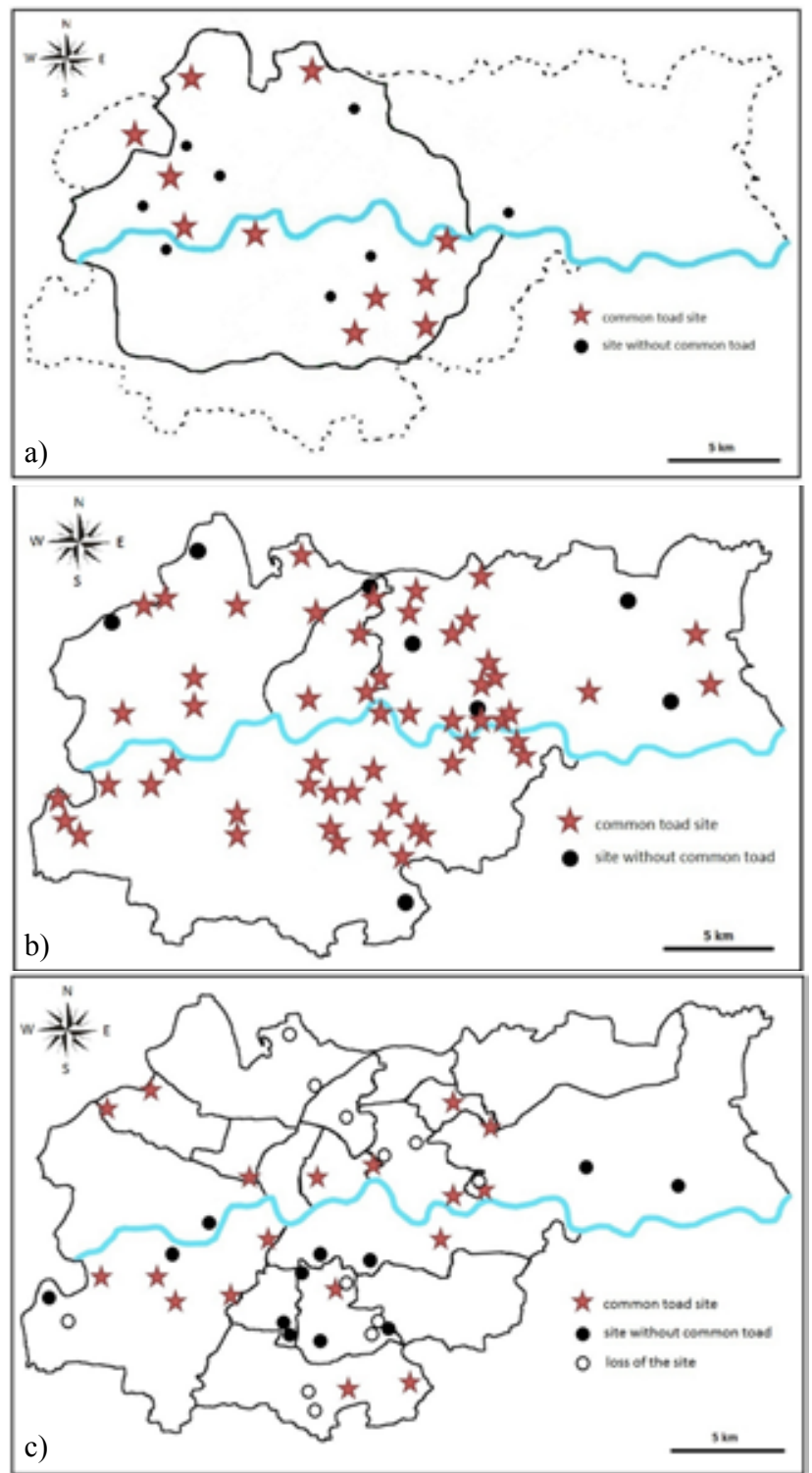

Figure 2. Distribution of the common toad in Kraków (within borders of the city districts) during three inventory periods: a) 1928-1939 (Juszczyk 1989), b) 1986-1992 (Guzik et al. 1996), c) 2011-2012 (present study) 


\subsubsection{Study sites}

The initial set of 42 water bodies which were planned for the research (Fig. 1) was prepared mainly (36 sites) on the basis of data from the previous inventory (Guzik et al. 1996). During the study, the set was narrowed to 30 water bodies (Fig. 2c), which turned out to be occupied by amphibians. The studied water bodies were located in 14 districts of Kraków, mainly in the central part of the city. More than half $(53 \%)$ of the water bodies were located in the vicinity of forests, meadows and wastelands (within a radius of at least $300 \mathrm{~m}$ ), while the remaining $47 \%$ were located in urban areas with a greater or lesser share of meadows, parks, allotments and woodlots. 12 water bodies were situated in the immediate vicinity of busy roads. The area of surveyed water reservoirs ranged from 2.4 a. to more than $28.0 \mathrm{ha}$. In terms of area the water reservoirs can be divided into: 'small' - up to 20.0 a. (mean $=9.83$ a., $\mathrm{SD}=5.48$ a.), 'medium' - between 20.0 a. and 200.0 a. (mean $=78.46$ a., SD $=59.11$ a.) and 'large' - more than 200.0 a. $($ mean $=1764.0$ a., $S D=1056.01$ a.). These three types of water body constituted consecutively $40 \%, 50 \%$ and $10 \%$ of the surveyed water bodies. Two water bodies had concrete bottoms and edges, without aquatic vegetation. Apart from them, there was aquatic vegetation in all surveyed water bodies.

\subsection{Methods}

The study was conducted during two amphibian breeding seasons (March-June in 2011 and 2012) in Kraków city. During March and April each site was monitored twice a month, while in May and June, once a month. All water bodies were surveyed on foot. The inspections consisted of observations of the water body, its edges and its vicinity. The surveys were conducted at different times of the day, either in the morning or in the evening. With the exception of the spring migration season of amphibians (March/April), when there was often moist and cloudy weather, the surveys were usually conducted in sunny and dry weather. The duration of each survey was 0.5 to 1.5 hours, depending on the size of the water reservoir. The presence of amphibians (both the common toad and other species) was determined on the basis of: direct observation of adults and juveniles, the presence of spawn, tadpoles and larvae, male mating calls and of the presence of dead animals near water bodies. The species of amphibians were determined according to the classification key of amphibians (Głowaciński \& Rafiński 2003). All observed green frogs were classified as Pelophylax kl. esculentus.

Data on the common toad and other amphibian distribution in Kraków was collected from literature (Juszczyk 1989; Guzik et al. 1996). The data on the occurrence of amphibians in Kraków in three periods were used to pre- sent the current situation of amphibians: 1) before the Second World War (1928-1939) when the nature of the city seemed to be the least exposed to threats, 2) after the rapid urban transformation associated with the expansion of the territory of the city (1986 -1992) and 3) the present time (2011-2012).

The used literature stated that the proportion of occupied habitat $(\mathrm{POH})$ by the common toad or any other amphibian species refers to the number of habitats containing the species in relation to the number of all existing and studied amphibian habitats over a given period of time. Three categories of species attendance were established: common: $\mathrm{POH}>0.70$; frequent: $0.70 \geq \mathrm{POH} \geq 0.30$ and rare: $\mathrm{POH}<0.30$.

\section{Results and discussion}

During the study, the loss of 12 water bodies previously studied by Guzik et al. (1996) was reported. The remaining 30 water bodies were habitats of amphibians. The presence of the common toad was found in 18 localities (Fig. 2c). Besides the Bufo bufo, the following species were also observed: the common frog Rana temporaria (Linnaeus, 1758), the moor frog Rana arvalis (Nilsson, 1842), the green frogs Pelophylax kl. esculentus, the green toad Pseudepidalea viridis (Laurenti, 1768), the common spadefoot Pelobates fuscus (Laurenti, 1768), the fire-bellied toad Bombina bombina (Linnaeus, 1761), the European tree frog Hyla arborea (Linnaeus, 1768), the great crested newt Triturus cristatus (Laurenti, 1768) and the smooth newt Lissotriton vulgaris (Linnaeus, 1758). The same species composition (Table 1) was noted in the past by Juszczyk (1989) and Guzik et al. (1996). The proportion of occupied habitat $(\mathrm{POH})$ by the common toad in the years 1927-2012 varied (Table 1, Fig. 3). In the interpretation it must be remembered that the data come from different groups of localities, but this is the only available information. Furthermore, it should be taken into account that the significant difference between the values of $\mathrm{POH}$ may be influenced by the slightly different methodology of each of the researchers. The current research of amphibian habitats, as in the case of Juszczyk (1989), concerned only water bodies. However, Guzik et al. (1996) inventoried not only water bodies, but also forests, parks and allotments. The number of studied amphibian sites varied too. In the years 1927-1939 there were 19 water bodies, in the years 1985-1992 there were 63 sites and in the present time (2011-2012) there were 30 water bodies. It could be possible to get a larger number of common toad habitats by expanding the number and type of amphibian habitats to the ones investigated by Guzik et al. (1996), but this case requires further study. 
Table 1. The frequency of amphibians by the proportion of occupied habitat $(\mathrm{POH})$ by each amphibian species in the three inventory periods: 1928-1939 (Juszczyk 1989), 1986-1992 (Guzik et al. 1996) and 2011-2012 (the present study)

\begin{tabular}{lccc}
\hline Amphibian species & $1927-1939$ & $1986-1992$ & 2011-2012 \\
\hline Rana temporaria & 0.95 & 0.92 & 0.57 \\
Rana arvalis & 0.53 & 0.22 & 0.10 \\
$\begin{array}{l}\text { Pelophylax kl. } \\
\text { esculentus }\end{array}$ & 0.84 & 0.76 & 0.80 \\
Bufo bufo & 0.58 & 0.86 & 0.57 \\
Pseudepidalea viridis & 0.84 & 0.54 & 0.10 \\
Pelobates fuscus & 0.89 & 0.14 & 0.03 \\
Bombina bombina & 0.89 & 0.36 & 0.27 \\
Triturus cristatus & 0.89 & 0.19 & 0.10 \\
Lissotriton vulgaris & 0.89 & 0.71 & 0.33 \\
\hline
\end{tabular}

In the prewar period there were numerous amphibians in Kraków. Within the studied habitats, Juszczyk (1989) recorded a majority of amphibians living in the city. The common toad, as the moor frog, was the only species that can be identified as a frequent species (not common) in this period (Table 1). In the 80 s and 90 s of the twentieth century, when Kraków had already undergone a lot of changes in urban planning, the common toad numbers increased in contrast to other amphibian species. The $B$. bufo was then the second most numerous amphibian (occupied habitats) in Kraków, and with the common frog, the green frog and the smooth newt, it was a common species. In the present time, the number of common toad, like other species of

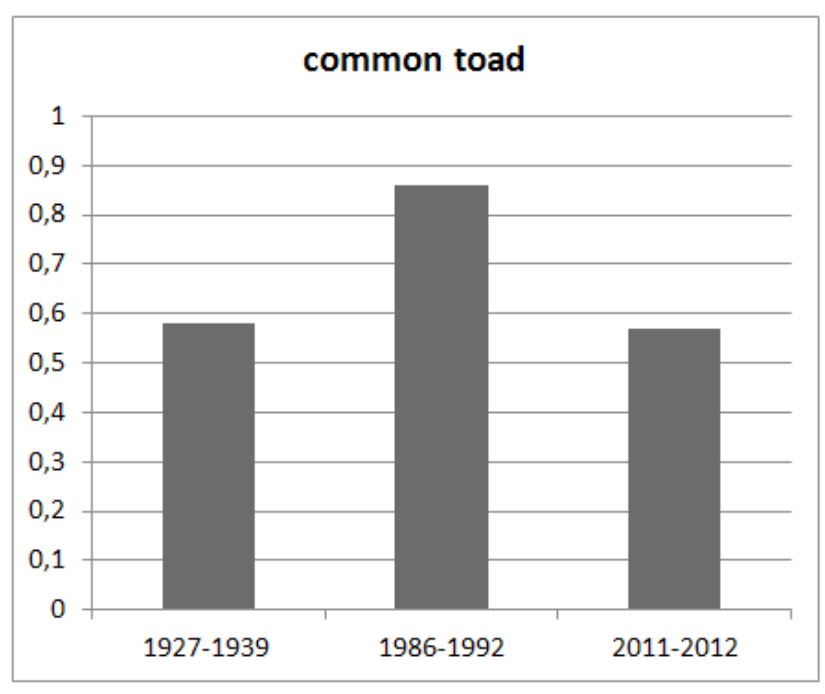

Figure 3. Histogram of frequency (proportion of occupied habitat $-\mathrm{POH})$ of the common toad in Kraków during three inventory periods

amphibian (except the green frog), has decreased (Table 1, Fig. 3 and 4).

Juszczyk (1989), during his first Kraków research inventory (1922-1927) did not note the common toad. Thus, this species probably started to spread in the late 20 s of the twentieth century (Fig. 2a). The increase in the number of common toad at a time when other species were found in the decline (Table 1) is probably due to its high environmental plasticity. Together with changes in the urban areas of Kraków, farmland, meadows, orchards and gardens gradually disappeared, and with them the natural environment of amphibian life. The common toad seems to be the only species that could deal with these changes and with the loss of habitat. However, further changes in the

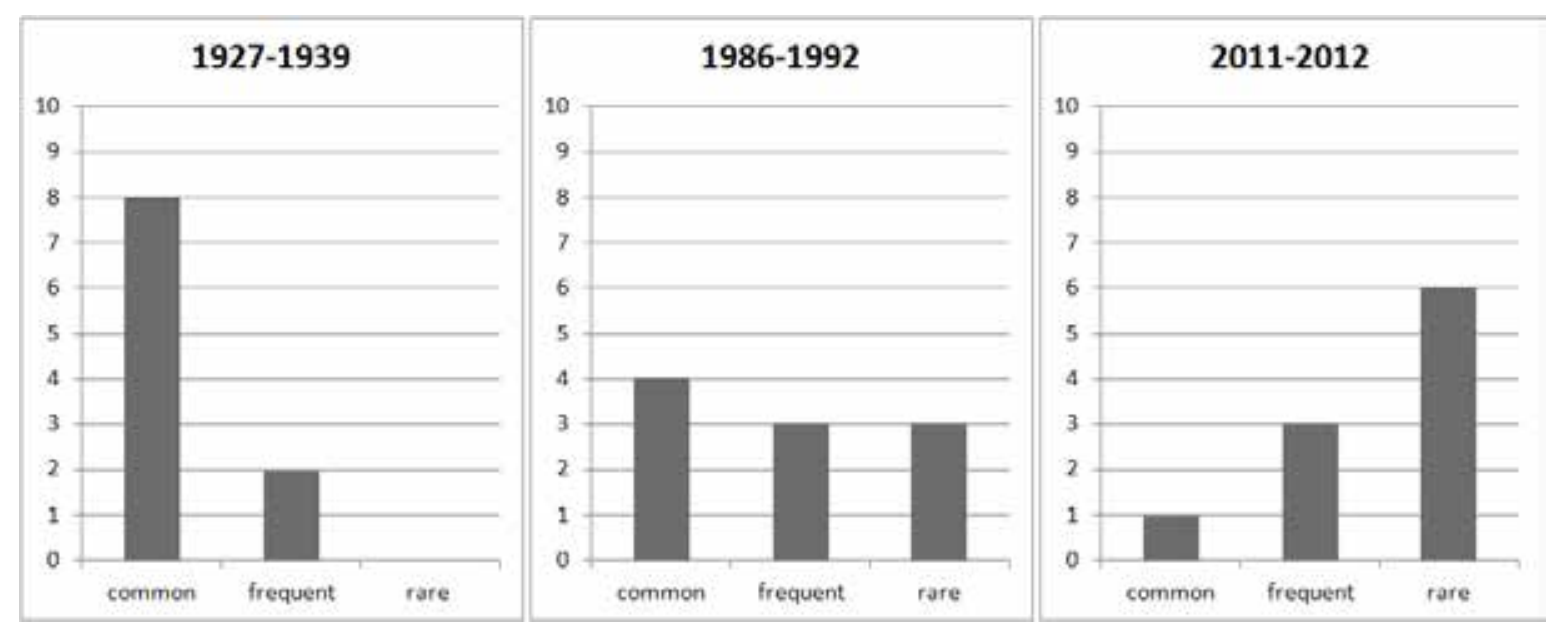

Figure 4. Number of species found as common, frequent and rare in Kraków during three inventory periods 
following years lead to a weakening of the population of this species and, like the others, it is now in decline. This fact appears to confirm the analysis of the B. bufo distribution in the city. For example, in the southeastern part of Kraków the common toad was particularly numerous in the years 1985-1992 (Guzik et al. 1996), but the number of housing estates being built led to the fact that the species is currently almost absent there (Fig. 2b, c).

\section{Conclusion}

Recent studies have shown a decrease in the number of amphibian habitats in the past nearly 90 years. Among the selected 36 sites inventoried in 1985-1992 by Guzik et al. (1996), the loss of 12 was shown. Both Juszczyk (1989) and Guzik et al. (1996) also noted habitat loss in their research. The main reasons mentioned by the authors were: the liquidation of under buildings, landfills, wastewater and eutrophication. Currently, the main reason for habitat decline is still their liquidation due to changes in urban development. Among the amphibians, the common toad seems to be one of the most resistant to urbanization changes. However, very strong impact, sooner or later, may lead to the amphibian's extinction. Therefore, amphibians in the urban environment should be subject to special attention and any investments leading to their habitat destruction should be compensated by the creation of new habitats for this valuable group of animals.

\section{References}

Baillie J. E. M., Hilton-Taylor C. \& Stuart S. N., 2004, A 2004 IUCN Red list of threatened species: A Global Species Assessment, IUCN, Gland, Switzerland and Cambridge, UK.

Beebee T. J. C. \& Griffiths R. A., 2005, The amphibian decline crisis: a watershed for conservation biology?, Biological Conservation 125: 271-285.

Cushman S. A., 2006, Effects of habitat loss and fragmentation on amphibians: a review and prospectus, Biological Conservation 128: 231-240.

Głowaciński Z., 2003, Ropucha szara Bufo bufo (Linneus, 1758) [The common toad Bufo bufo (Linneus, 1758)], [in:] Z. Głowaciński, J. Rafiński (eds.), Atlas płazów i gadów Polski. Status - Rozmieszczenie - Ochrona [Atlas of the amphibians and reptiles of Poland. Status - Distribution - Conservation], Biblioteka Monitoringu Środowiska, IOŚ/IOP PAN, Kraków - Warszawa: 47-50.

Głowaciński Z. \& Rafiński J., 2003, Atlas płazów i gadów Polski. Status - Rozmieszczenie - Ochrona [Atlas of the amphibians and reptiles of Poland. Status - Distri- bution - Conservation], Biblioteka Monitoringu Środowiska, IOŚ/IOP PAN, Kraków - Warszawa.

Guzik M., Schimscheiner L., Zakrzewski M., Zamachowski W. \& Zyśk A., 1996, Herpetofauna miasta Krakowa [Herpetofauna of the city of Kraków], Studia Ośr. Dok. Fizjograf. PAN, Kraków: 24: 247-262.

Hamer A. J. \& McDonnell M. J., 2008, Amphibian ecology and conservation in the urbanising world: A review, Biological Conservation 141: 2432-2449.

Juszczyk W., 1987, Płazy i gady krajowe [Amphibians and reptiles of Poland], PWN, Warszawa.

Juszczyk W., 1989, Płazy i gady miasta Krakowa w latach 1922-1979 [Amphibians and reptiles in the city of Kraków in 1922-1979], Przegląd Zoologiczny 33: 373-381.

Kawa K., Budzik K., Żuwała K. \& Bury S., 2011, The amphibian species composition of selected Kraków water bodies over the last decades, [in:] P. Indykiewicz, L. Jerzak, J. Böhner, B. Kavanagh (eds), Urban Fauna. Studies of animal biology, ecology and conservation in European cities, Uniwersytet Techniczno-Przyrodniczy, Bydgoszcz: 349-356.

Kawalec W., 1998, Monitoring miejsc rozrodu populacji płazów w Krakowie [Monitoring of amphibians breeding sites of Kraków], Praca licencjacka, Zakład Anatomii Porównawczej, Uniwersytet Jagielloński, Kraków.

Miltner R. J., White D. \& Yoder C., 2004, The biotic integrity of streams in urban and suburbanizing landscapes, Landscape and Urban Planning 69: 87-100.

Najbar B., 2010, The occurrence of amphibians in Zielona Góra in 2005-2008, Fragmenta Faunistica 53: 181-194.

Ogielska M. \& Kierzkowski P., 2010, Long term data on the amphibians of Wrocław, Fragmenta Faunistica 53: 195-2012.

Paul M. J. \& Meyer J. L., 2001, Streams in the urban landscape, Annual Review of Ecology and Systematics 32: 333-365.

Stebbins R. C. \& Cohen N., 1995, Natural history of amphibians, Princeton University Press, Princeton.

Stuart S. N., Chanson J. S., Cox N. A., Young B. E., Rodrigues A. S. L., Fischman D. L. \& Waller R. W., 2004, Status and trends of amphibian declines and extinctions worldwide, Science 306:1783-1786.

Wilkinson J. W. \& Buckley J., 2012, Amphibian Conservation in Britain, FrogLog 101: 12-13. 